\title{
The phenomenal determination of retroaction and proaction: IV. The role of contextual and temporal factors with highly differentiated lists
}

\author{
LEONARD BROSGOLE and PATRICIA M. SCHIANO \\ St. John's University, Jamaica, New York 11439
}

\begin{abstract}
A study was run on retroaction and proaction in which subjects had to learn two lists of pairs, consisting of color names and common nouns. The lists, which were highly differentiated by use of meaningful response items, were embedded within the context of two stories. One story related to Christmas Eve and the other, to New Year's Eve. Thus, story context was used to establish a sequential relationship between the lists. Group 1 learned the Christmas Eve story first and the New Year's Eve story last; Group 2 learned the stories in reverse order. For Group 2, there was a conflict between the contextual sequence and the temporal order of presentation. Delayed recall was assessed after $20 \mathrm{~min}$ and after $24 \mathrm{~h}$ to determine whether retroaction and proaction were affected in Group 2 by the conflict between the contextual cue to order and the temporal cue to order. There were no interference effects observed in either of the groups, as expected under conditions of list differentiation.
\end{abstract}

In a recent study, Brosgole and Grosso (1982) showed that retroaction is affected by the manner in which two lists are organized sequentially in memory. While the perception of order may be established by the temporal sequence of presentation (i.e., List 1 may be sensed as preceding List 2 simply because it was learned first in time), so too may it be affected by the context within which the materials are learned. The question was raised as to whether retroactive interference (RI) and proactive interference (PI) would be influenced by generating a conflict between the temporal and contextual cues to phenomenal order or sequence.

In order to generate such a conflict, two lists of paired associates were constructed. Each list consisted of 12 color name/nonsense syllable pairs. The same color names appeared in both lists, but the CVC trigrams differed. Thus, an A-B,A-C paradigm was used to produce maximum interference. The lists, which were to be mastered to a partial criterion, were embedded within the context of two different stories. The first story pertained to Christmas Eve and the second, to New Year's Eve. These stories were used because they denote the beginning and end of a holiday season that is recognized universally within our culture. One group of subjects (Group 1) learned the Christmas Eve story followed by the New Year's Eve story, and a second group (Group 2) learned the two stories in the reverse order. While the contextual and temporal sequences were in agreement for Group 1, a clear cue-conflict situation was generated for Group 2. It was found that this competition between the contextual cue to order and the temporal cue to order resulted in a significant reduction of RI.

In the Brosgole and Grosso (1982) study, RI and PI were inferred from the significant interaction that was found between the stories and time. It may be argued that such an inference was inappropriate and that RI and PI can be assessed only by comparing the delayed recall data of an experimental group to that of a standard control, that is, to a group that learned only one set of materials. Although it would appear unnecessary to use such a conventional control when RI and PI are being tested simultaneously (as in the Brosgole and Grosso study), it is still legitimate to inquire as to whether the obtained effects are susceptible to the same manipulations as are the traditionally found phenomena.

In the present experiment, we attempted to create two highly differentiated stories by pairing the color names with meaningful, overlearned responses. It was reasoned that the use of differentiated materials should preclude the occurrence of RI and PI. Therefore, it follows logically that the present manipulation should have failed to produce a significant interaction between story and time (i.e., if interference effects were truly being observed in the Brosgole and Grosso, 1982, study).

\section{METHOD}

\section{Subjects}

Eleven males and nine females participated in this study. Ranging in age from 18 to 29 years, their mean age was 22.7 years. All subjects were naive as to the purpose of the experiment.

\section{Apparatus and Materials}

Two stories were created, one about Christmas Eve and the other about New Year's Eve. Each story contained 12 color names that were paired with common nouns. The color names served as the stimulus items for the pairs, and the nouns were the response items.

Each story was preceded by the word "start," which was centered in bold type. The same color names were used across stories, but the nouns differed. Thus, an A-B,A-C paradigm was 
employed to access retroaction and proaction. Delayed recall was obtained $20 \mathrm{~min}$ and $24 \mathrm{~h}$ after the completion of interpolated learning. All materials were presented on a Lafayette memory drum (Model 303).

The Christmas Eve story read as follows: "Bursting with excitement, I swiftly raced down the stairs into the living room to see what Santa had delivered the night before. While entering the room, I was immediately captured by the splendor of the Christmas tree, beautifully ornamented with glistening blue tinsel and softly twinkling colored lights. Gasping with delight, I gazed at the holiday style decorated presents which surrounded the magnificent evergreen. To the right of the tree stood a stunning, silver, ten-speed bicycle garnished on the handle bars with a big, pink bow. A large rectangular shaped package decorated with green foil and yellow velvet ribbon lay directly at the foot of the tree. To the left of the box sat a beautiful red haired doll wearing a lavender dress trimmed with white lace, and black patent leather shoes. Two small packages hung from the base of the tree; one was wrapped in orange paper while the other was a gold box bound by brown string. As I beheld this wondrous sight I could not help being filled with the jubilant holiday spirit."

The New Year's Eve story was as follows: "Beaming with the joy and merriment of the holiday season, I vivaciously pranced into the party room filled with friends and relatives to festively partake in the arrival of the New Year. Upon entering the room, I was delightfully enchanted with the jubilant mood of the guests who were wishing each other holiday cheer while waving crystal glasses filled with pink champagne. Happily, I stared at the host, who was preparing the food and drink buffet style on the table in the middle of the high spirited celebration. To the right of the table stood my uncle wearing a blue, cone-shaped hat decorated with silver sparkles. At his feet sat a big, white box filled with orange streamers and brown confetti. Looking into the box was my little, black haired cousin wearing a green party cap decorated with gold fringe. By the Christmas tree, two of my fondest friends joined in the merry making of the evening; one was shaking a yellow noise maker while the other was blowing a red horn with lavender polka dots. As I joined the celebration I could not help being overcome by the joyous feeling of anticipating the New Year."

\section{Groups}

The subject pool was divided into two equally sized groups. Group 1 learned the Christmas Eve story followed by the New Year's Eve story, and Group 2 learned them in reverse order. Subjects were randomly assigned to each group.

\section{List Construction}

Two groups of eight subjects were equated for learning ability on a matching list of paired associates, consisting of color names and nonsense syllables. The nonsense syllables were of $50 \%$ frequency value, according to the Archer (1960) list. While one group then learned the Christmas Eve story to full criterion, the other learned the New Year's Eve story. The Christmas Eve story was learned in an average of 3.5 trials with 12.63 errors, and the New Year's Eve story was learned fully in 4.25 trials with 14.75 errors. An analysis of the data indicated that the two stories were learned in essentially the same number of trials, with a like number of errors. Therefore, they were considered to be of comparable difficulty.

\section{Procedure}

The subjects were told that this was a two-part experiment in which we were attempting to gather adult norms in the learning of stories that will subsequently be presented to children. They were informed that they would be required to learn a different set of stories upon returning the next day. This subterfuge was used to prevent rehearsal prior to the 24-h test of recall. The actual purpose of the study was disclosed at the completion of the second test session.

Subjects from both groups were tested for recall after each trial on their respective first story. The story was presented line by line at a 4-sec rate with no delay between lines, with the subjects instructed to read the story aloud upon each presentation. In addition, the subjects were informed that, after each trial, they would be presented a list of the 12 colors taken from the story and that their task was to name aloud the object that went with each of the colors. Thus, the method of cued or aided recall was used in which the color names were presented at a 2 -sec rate with no interstimulus interval. These test stimuli were presented in six different orders, which were varied over trials. The trials continued until a partial criterion of six to eight correct responses was achieved.

Each group was given the appropriate second story immediately afterward. The same procedure was used as in the previous task. After a criterion of six to eight correct responses was achieved, the subjects were allowed a 20-min break. They were then presented each of the 12 color names, individually, and were required to give the associated common nouns from both of the stories, with no time restrictions placed on the task. The subjects returned $24 \mathrm{~h}$ later, and the same test of delayed recall was repeated. Thus, each group was tested for recall after $20 \mathrm{~min}$ and after $24 \mathrm{~h}$.

\section{RESULTS AND DISCUSSION}

The recall data were subjected to a 2 by 2 by 3 splitplot factorial analysis of variance, using a square-root transformation to correct for small frequencies. There were two within-subjects factors, namely, story (first and second, regardless of content) and time (number of response items recalled on the last learning trial, $20 \mathrm{~min}$ and $24 \mathrm{~h}$ later). Group ( 1 and 2 ) was the sole betweensubjects factor. The analysis revealed a significant main effect of time $[F(2,36)=40.72, p<.01]$. There were no other significant main effects or interactions.

Because time failed to interact with any other factor, the recall data were collapsed over stories and groups and the main effect of time was evaluated further by use of the Newman-Keuls test. There were an average of 6.95 correct responses on the last learning trial, 5.82 at the 20-min interval, and 4.62 after a 24 -h delay. The Newman-Keuls test indicated that there was a significant decrease in recall at $20 \mathrm{~min}(\mathrm{p}<.01)$ and a further decrement from $20 \mathrm{~min}$ to $24 \mathrm{~h}(\mathrm{p}<.01)$.

Thus, it would appear that there was a total failure to generate interference effects with the use of highly differentiated materials. Therefore, it could not be contended that the results of Brosgole and Grosso (1982) were the spurious outcome of either a unique procedure for presenting materials or an inappropriate statistical inference. This study provided for a control, ensuring the legitimacy of the previously obtained effect.

\section{REFERENCES}

Archer, J. E. A re-evaluation of the meaningfulness of all possible CVC trigrams. Psychological Monographs: General and Applied, 1960, 3(Whole No. 497).

Brosgole, L., \& Grosso, J. J. The phenomenal determination of retroaction and proaction: III. Contextual vs. temporal organization of two lists. Bulletin of the Psychonomic Society, 1983, 21, 15-18.

(Received for publication November 4, 1982.) 